\title{
POLITICAL WILL SEBAGAI STRATEGI MENGELOLA PEDAGANG KAKI LIMA (PKL) DI KOTA SURAKARTA
}

Wahyu Beny Mukti Setiyawan, Suharno, Widiatama; Universitas Islam Batik Surakarta; Jl. KH Agus Salim No. 10 Surakarta; E-mail :muktibeny@gmail.com, suharno.hukumuniba@gmail.com, maskulinb@gmail.com

\begin{abstract}
Abstrak
Penelitian ini bertujuan untuk mengetahui faktor-faktor apa saja yang menjadi kendala dalam mengefektifkan Peraturan Daerah Kota Surakarta Nomor 3 Tahun 2008 tentang Pengelolaan Pedagang kaki lima (PKL) di Kota Surakarta dan bagaimana mengefektifkan Peraturan Daerah Kota Surakarta Nomor 3 Tahun 2008 tentang Pengelolaan Pedagang Kaki Lima (PKL). Implikasi dari penelitian ini adalah untuk menciptakan efektivitas sebuah kebijakan diperlukan kerjasama yang baik (sinergitas) antara para penegak hukum dan juga pemerintah. Selain itu juga harus melibatkan peran serta dari masyarakat, baik masyarakat umum dan khususnya para pedagang kaki lima (PKL). Keberhasilan penataan Pedagang Kaki Lima (PKL) di Kota Surakarta dipengaruhi oleh faktor peran Walikota dalam mengkomunikasikan kebijakan (political will) yang akan diambilnya.
\end{abstract}

Kata kunci: Efektivitas, Pedagang Kaki Lima (PKL), Kota Surakarta.

\section{Abstract}

This research aims to find out what factors are becoming obstacles in streamline local regulations Surakarta number 3 the year 2008 regarding the management of street vendors in the city of Surakarta. The implication of this research is to create policy effectiveness needed good cooperation (synergy) between law enforcers and also the government. Besides, it should also involve the participation of the community, both the general public and particularly the street vendors. The success of the arrangement of street vendors in the city of Surakarta is affected by factors the role of Mayor in communicating policy (political will) to be taken.

Keywords: Effectiveness, Street Vendors, The City of Surakarta.

\section{PENDAHULUAN}

Pembangunan ekonomi di Negara Kesatuan Indonesia (NKRI) secara terencana dan mendasar yang dimulai sejak era orde baru, selain menghasilkan dan menumbuhkan industri dalam skala besar serta program resmi dari pemerintah yang diberikan istilah yaitu sektor formal, akan tetapi juga telah menumbuhkan usaha-usaha kecil yang dikelola secara mandiri dan memiliki kebebasan penuh dalam menjalankan usahanya yang diberikan istilah informal. Terkadang kehadiran sektor informal inilah, khususnya Pedagang Kaki lima (PKL), tidak begitu disukai oleh pemerintah dan juga golongan tertentu di dalam masyarakat.

Banyak dalih atau pernyataan dikemukakan untuk memberi pembenaran dari argumentasi penolakan ini, mulai dari terganggunya kelancaran lalu lintas (lalin), memberikan citra atau pemandangan buruk pada wajah kota dan lain-lain yang pada intinya itu berpandangan negatif. Celakanya citra atau pandangan yang paling negatif yaitu PKL dianggap sebagai sampah kota yang bersifat parasit. Demikian karena banyak itu atau biasanya PKL menempati emper-emper toko atau kios, berjejal di pojokpojok pasar, berderet-deret di pinggir jalan dan di tempat-tempat umum lainnya. 
Sebagaimana kota-kota besar lainnya di Indonesia, kota Surakarta itu menjadi kota perdagangan, karena ketatnya persaingan untuk dapat atau mampu bekerja pada sektor formal, hal itu menjadi wajar apabila para pengangguran atau orang yang belum mendapat pekerjaan melakukan kompensasi positif dengan memilih bekerja pada sektor informal. Salah satu sektor informal yang banyak diminati para pengangguran atau orang yang belum mendapat pekerjaan (selain yang sudah lama bekerja di sektor ini) adalah menjadi PKL. Sebagai bagian dari kelompok usaha kecil yaitu kelompok usaha yang tak terpisahkan dari aset pembangunan nasional yang berbasis kerakyatan, jelas merupakan bagian integral dari dunia usaha nasional yang mempunyai kedudukan, potensi dan peranan yang sangat strategis dalam hal untuk turut mewujudkan tujuan pembangunan nasional pada umumnya dan tujuan pembangunan ekonomi pada khususnya.

Terlepas dari potensi ekonomi pada sektor informal, keberadaan PKL di kotakota besar di NKRI kerap menimbulkan masalah baik bagi pemerintah setempat itu, para pemilik toko-toko atau kios-kios, pasar, tempat umum dan juga pengguna jalan. Tidak sedikit para pemilik toko-toko atau kios-kios, pasar, tempat umum dan juga pengguna jalan, merasa itu terganggu dengan membeludaknya serta tidak tertibnya PKL. Andai pemerintah melihat hal itu sebagai potensi sosial ekonomi yang bisa dikembangkan, maka kebijakan yang dipilih bisa diarahkan untuk menata, misalnya dengan memberikan ruang usaha dan memformalkan status mereka sehingga bisa memperoleh bantuan kredit bank misalnya. Namun sebaliknya, jika PKL hanya dilihat sebagai pengganggu atau parasit ketertiban dan keindahan kota, maka mereka itu akan menjadi sasaran penggusuran dan penertiban. Dalam hal ini, pemerintah kota Surakarta telah menggunakan beberapa strategi untuk menangani PKL, yaitu dengan relokasi, shelterisasi, tendanisasi dan gerobakisasi.

Dari keterangan diatas mengenai upaya merangkul PKL, kota Surakarta memiliki peraturan dengan Peraturan Daerah (Perda)nya yaitu Peraturan Daerah Kota Surakarta Nomor 3 Tahun 2008 tentang Pengelolaan Pedagang Kaki Lima (PKL). Peraturan daerah tersebut memiliki keefektifan, tantangan yang perlu diwaspadai dan dijabarkan untuk kedepannya serta dikembangkan baik dalam bentuk kebijaksanaan maupun gerak operasional para aparat penegak hukum serta peran serta masyarakat Khususnya PKL diharapkan berniat mendukung upaya pemerintah daerah untuk menegakkan peraturan daerah dan kebijakan pemerintah daerah.

\section{RUMUSAN MASALAH}

Bagaimanakah mengefektifkan Peraturan Daerah Kota Surakarta Nomor 3 Tahun 2008 tentang Pengelolaan Pedagang Kaki Lima (PKL) ? 


\section{KERANGKA BERFIKIR}

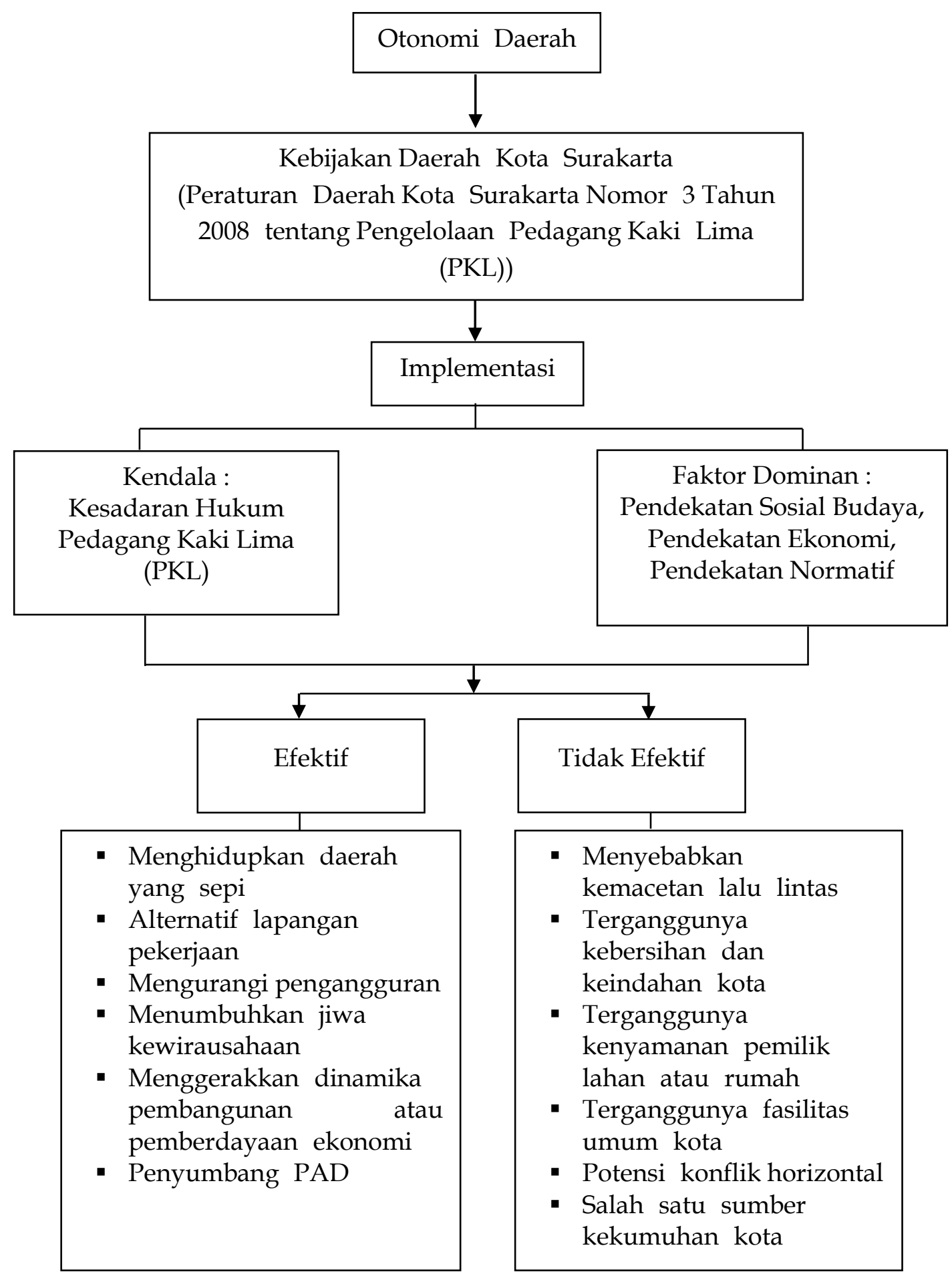




\section{METODE PENELITIAN}

\section{Jenis Penelitian}

Penelitian ini merupakan jenis penelitian empiris atau non doktrinal (socio legal reseach). Dalam hal ini, hukum dikonsepsikan sebagai pranata sosial yang secara riil dikaitkan dengan variabel-variabel sosial yang lain.

\section{Sifat dan Bentuk Penelitian}

Ditinjau dari sifatnya penelitian ini termasuk penelitian hukum yang bersifat deskriptif, maksudnya adalah suatu penelitian yang dimaksudkan untuk memberikan data-data yang seteliti mungkin tentang manusia, keadaan atau gejala lainnya. Penelitian ini bertujuan untuk mengkaji dan memberikan data terkait efektivitas Peraturan Daerah Kota Surakarta Nomor 3 Tahun 2008 tentang Pengelolaan Pedagang Kaki Lima (PKL) di Kota Surakarta.

Bentuk penelitian ini merupakan penelitian evaluatif, yaitu untuk mengetahui dan mengkaji serta menilai efektivitas Peraturan Daerah Kota Surakarta Nomor 3 Tahun 2008 tentang Pengelolaan Pedagang kaki lima (PKL) di Kota Surakarta.

\section{Pendekatan Penelitian}

Penelitian ini menggunakan pendekatan kualitatif. Menurut Soerjono Soekanto, pendekatan kualitatif adalah suatu penelitian yang menghasilkan data deskriptif analisis, yaitu apa yang dinyatakan responden secara tertulis atau lisan dan juga perilaku nyata, yang diteliti dan dipelajari sebagai sesuatu yang utuh.

\section{Lokasi Penelitian}

Penelitian ini dilakukan di wilayah Kota Surakarta atau sumber pencarian data berasal dari berbagai instansi atau lembaga atau organisasi atau pusatpusat informasi dan dokumentasi lain yang memiliki kapasitas untuk menyediakan bahan-bahan penelitian yaitu bagian Hukum dan Hak Asasi Manusia (HAM) SETDA Kota Surakarta dan bagian Bidang Pengelol aan Pedagang kaki lima (PKL) pada Dinas Pengelolaan Pasar Pemerintah Kota Surakarta.

\section{Jenis Data Penelitian}

Data yang digunakan untuk mendukung penelitian ini terdiri dari :

a. Data primer yaitu data yang diperoleh langsung dari lapangan atau lokasi penelitian (field research).

b. Data sekunder yaitu merupakan data yang diperoleh peneliti dari bahanbahan kepustakaan yang berupa literatur yang berkaitan dengan permasalahan yang akan diteliti.

Data sekunder ini pun masih dibagi menjadi 3 bagian lagi yakni :

1) Bahan hukum primer yaitu bahan-bahan yang terdiri peraturan perundangundangan yang terkait dengan penelitian ini.

2) Bahan hukum sekunder yaitu bahan hukum yang berfungsi sebagai penjelas dari bahan hukum primer. 
3) Bahan hukum tersier yaitu bahan-bahan pendukung atau sebagai pelengkap bahan hukum sekunder.

\section{Teknik Pengumpulan Data}

Guna memperolah data yang sesuai dan mencakup permasalahan dalam penelitian ini, peneliti menggunakan beberapa teknik pengumpulan data yang dilakukan melalui 3 (tiga) cara sebagai berikut :

a. Pertama

Pra survei dilakukan pengambilan data awal di instansi terkait yaitu pada bagian Hukum dan Hak Asasi Manusia (HAM) SETDA Kota Surakarta dan bagian Bidang Pengelolaan Pedagang Kaki Lima (PKL) pada Dinas Pengelolaan Pasar Pemerintah Kota Surakarta untuk lebih memudahkan langkah pengumpulan data selanjutnya.

b. Kedua

Pengumpulan data dengan wawancara. Wawancara adalah percakapan dengan maksud tertentu. Percakapan tersebut dilakukan dengan dua orang pihak, yaitu pewawancara (interviewer) yang mengajukan pertanyaan dan yang diwawancarai (interview) yang memberikan jawaban atas pertanyaan itu. Wawancara sangat diperlukan untuk memperoleh data yang sebenarnya dan yang diberi pertanyaan adalah orangorang yang terkait dengan penelitian.

c. Ketiga

Studi kepustakaan adalah suatu teknik pengumpulan data dengan mencari data-data sekunder yang terdiri dari bahan hukum primer, bahan hukum sekunder dan bahan hukum tersier yang relevan dengan permasalahan yang diteliti. Pengumpulan data dengan studi pustaka dimaksudkan untuk mendukung penelitian ini. Berupa pengumpulan Peraturan perundang-undangan, jurnal-jurnal, buku-buku (literatur), dan bahan pustaka lain yang berkaitan dengan pembahasan penelitian ini.

\section{HASIL PENELITIAN DAN PEMBAHASAN}

Keadilan dalam hukum merupakan keseimbangan kepentingan. Hukum justru yang menjadi instrumen untuk mengarahkan masyarakat menuju kepada tujuan yang diinginkan, bahkan kalau perlu, menghilangkan kebiasaan masyarakat yang dipandang negatif. Hukum sebagai social engineering yang ditekankan adalah menata kepentingankepentingan yang ada dalam masyarakat. Kepentingan-kepentingan tersebut harus ditata sedemikian rupa agar tercapai keseimbangan yang profesional. Dalam hal ini, kepentingan dari Pemerintah Kota (Pemkot) Surakarta dan kepentingan masyarakat khususnya para Pedagang Kaki Lima tersebut harus berjalan secara seimbang.

Dengan adanya Peraturan Daerah Kota Surakarta Nomor 3 Tahun 2008 tentang Pengelolaan Pedagang Kaki Lima, diharapkan dapat mewujudkan keadilan hukum yang dapat menata kepentingan-kepentingan yang ada dalam masyarakat. Kepentingan dari Pemerintah Kota (Pemkot) Surakarta adalah membangun Kota Surakarta menjadi lebih 
baik yaitu terciptanya penataan, ketertiban dan estetika kota dalam pengelolaan Pedagang Kaki Lima di Kota Surakarta. Kepentingan dari masyarakat khususnya para Pedagang Kaki Lima adalah mendapat ruang yang lebih baik dan nyaman untuk mata pencahariannya. Untuk mewujudkan kepentingan yang seimbang itu maka harus ada penegakan hukum yang tegas dalam pengelolaan Pedagang Kaki Lima.

Dalam menegakan Peraturan Daerah Kota Surakarta Nomor 3 Tahun 2008 tentang Pengelolaan Pedagang Kaki Lima dibutuhkan kerjasama yang baik diantara para penegak hukum dan juga pemerintah. Selain itu juga harus melibatkan peran serta dari masyarakat, baik masyarakat umum dan khususnya para Pedagang Kaki Lima. Karena harus seimbang antara kepentingan pencipta dalam hal ini Pemerintah Kota (Pemkot) Surakarta dengan kepentingan masyarakat yaitu kesamaan bahwa mereka sama-sama ingin membangun Kota Surakarta menjadi lebih baik. Oleh karena itu, sangat diperlukan kesadaran hukum dari berbagai pihak. Kesadaran hukum sejatinya adalah kesadaran akan hak dan kewajiban dari individu-individu, kesadaran akan tanggung jawab sebagai individu serta sebagai anggota masyarakat.

Kesadaran hukum masyarakat merupakan faktor yang melatarbelakangi lemahnya penegakan hukum penataan dan penertiban Pedagang Kaki Lima di Kota Surakarta. Penegakan hukum merupakan proses untuk mewujudkan pikiran-pikiran pembuat undang-undang yang dirumuskan dalam peraturan-peraturan hukum menjadi nyata. Penegakan hukum tidak bisa lepas dari kesadaran hukum warga masyarakat, ketika kesadaran warga masyarakat terhadap hukum tinggi mengakibatkan warga masyarakat mematuhi Peraturan Perundang-undangan yang berlaku. Sebaliknya, apabila kesadaran warga masyarakat rendah maka derajat untuk mematuhi peraturan tersebut juga rendah.

Sikap acuh dan apatis merupakan fenomena respons Pedagang Kaki Lima atas upaya penataan, pemberdayaan dan penertiban Pedagang Kaki Lima Kota Surakarta. Penegakan hukum penataan, pemberdayaan dan penertiban Pedagang Kaki Lima di Kota Surakarta dan upaya Pemerintah Kota Surakarta dalam mengefektifkan Peraturan Daerah Kota Surakarta Nomor 3 Tahun 2008 tentang Pengelolaan Pedagang Kaki Lima di Kota Surakarta akan semakin parah apabila tidak ada upaya untuk mengatasinya. Hal ini merupakan tantangan yang besar bagi Pemerintah Kota (Pemkot) Surakarta. Untuk mengefektifkan Peraturan Daerah Kota Surakarta Nomor 3 Tahun 2008 tentang Pengelolaan Pedagang Kaki Lima di Kota Surakarta, Pemerintah Kota Surakarta berupaya meningkatkan kesadaran hukum masyarakat dengan melakukan pendekatan dan memberikan yaitu :

a. Pengetahuan hukum, yaitu dengan mengadakan sosialisasi yaitu pembinaan, pemantauan dan pengawasan, sehingga diharapkan masyarakat mempunyai pengetahuan hukum yang benar dan mengetahui betapa pentingnya penataan, pemberdayaan dan penertiban Pedagang Kaki Lima di Kota Surakarta terhadap estetika kota agar Kota Surakarta menjadi lebih baik.

b. Pemahaman hukum, yaitu memberikan pemahaman kepada masyarakat mengenai Peraturan Daerah Kota Surakarta Nomor 3 Tahun 2008 tentang Pengelolaan Pedagang Kaki Lima, sehingga warga masyarakat mengetahui muatan yang ada dalam 
peraturan tersebut. Dengan mengetahui muatan itu, diharapakan masyarakat memahami tujuan Peraturan Daerah tersebut serta manfaat bagi masyarakat.

c. Penataan hukum, yaitu untuk menaati hukum maka warga masyarakat harus diberi pemahaman apa saja sebab-sebab hukum harus ditaati, dalam hal ini yaitu Peraturan Daerah Kota Surakarta Nomor 3 Tahun 2008 tentang Pengelolaan Pedagang Kaki Lima. Salah satunya agar Pedagang Kaki Lima di Kota Surakarta dapat menjadi semakin tertib dan terkondisikan.

d. Pengharapan hukum, yaitu untuk meningkatkan penegakan hukum tentang penataan dan penertiban Pedagang Kaki Lima di Kota Surakarta, warga masyarakat selain mengetahui, memahami dan menaati saja tidak cukup. Akan tetapi, warga masyarakat harus dapat merasakan bahwa penataan, pemberdayaan dan penertiban Pedagang Kaki Lima di Kota Surakarta tersebut dapat mewujudkan suatu ketertiban, ketentraman dan estetika kota agar Kota Solo menjadi lebih baik.

e. Peningkatan kesadaran hukum, yaitu peningkatan kesadaran hukum ini dapat dilakukan dengan mengadakan penyuluhan-penyuluhan terkait pentingnya penataan, pemberdayaan dan penertiban Pedagang Kaki Lima di Kota Surakarta. Masyarakat harus mengetahui mengetahui manfaat dari adanya Peraturan Daerah Kota Surakarta Nomor 3 Tahun 2008 tentang Pengelolaan Pedagang Kaki Lima. Sehingga diharapkan kesadaran hukum masyarakat akan timbul dan meningkat.

Kesadaran hukum dapat ditanamkan sedini mungkin terhadap warga masyarakat, yang dimana tidak hanya berupa pendidikan yang formal akan tetapi juga melalui edukasi, sosialisasi dan kegiatan lain yang bertujuan menimbulkan kesadaran hukum dalam diri masyarakat itu. Pada dasarnya, kesadaran hukum masyarakat itu dipengaruhi oleh pemahaman masyarakat akan hukum itu sendiri. Kesadaran hukum merupakan suatu bentuk kesadaran untuk menilai mana yang baik dan tidak baik serta untuk menilai hukum yang adil dan tidak adil. Sampai saat ini masih banyak masyarakat yang masih buta akan hukum. Apalagi Peraturan Perundang-undangan mengatakan bahwa masyarakat dianggap tahu hukum. Padahal terkadang sosialisasi Peraturan Perundangundangan masih kurang.

Kesadaran hukum masyarakat ini erat kaitannya dengan budaya hukum masyarakat, ketika kesadaran hukum masyarakat tinggi maka akan terwujud suatu budaya hukum yang baik, yaitu budaya hukum yang menjunjung tinggi, menghormati dan memberikan apresiasi terhadap Peraturan Daerah Kota Surakarta Nomor 3 Tahun 2008 tentang Pengelolaan Pedagang Kaki Lima. Karena Peraturan Daerah (Perda) ini diharapkan dapat mewujudkan keadilan hukum yang dapat menata kepentingan-kepentingan yang ada dalam masyarakat. Kepentingan dari Pemerintah Kota (Pemkot) Surakarta adalah membangun Kota Surakarta menjadi lebih baik yaitu terciptanya penataan, ketertiban dan estetika kota dalam pengelolaan Pedagang Kaki Lima di Kota Surakarta. Kepentingan dari masyarakat khususnya para Pedagang Kaki Lima adalah mendapat ruang yang lebih baik dan nyaman untuk mata pencahariannya. Sebaliknya ketika suatu kesadaran hukum masyarakat rendah maka akan terbentuk budaya hukum yang buruk, para Pedagang Kaki Lima di Kota Surakarta akan beranggapan bahwa Peraturan Daerah Kota Surakarta Nomor 3 Tahun 2008 tentang Pengelolaan Pedagang Kaki Lima, 
Peraturan Daerah (Perda) tersebut akan membawa dampak negatif yang dirasakan oleh Pedagang Kaki Lima yaitu tempat ganti yang kurang strategis dan tidak ramai pembeli bahkan mereka merasa dengan adanya penataan dan penertiban, para Pedagang Kaki Lima di Kota Surakarta akan kehilangan mata pencahariannya.

Untuk itu diperlukan komunikasi yang harmonis dan dibutuhkan kerjasama yang baik diantara para penegak hukum dan juga pemerintah. Selain itu juga harus melibatkan peran serta dari masyarakat, baik masyarakat umum dan khususnya para Pedagang Kaki Lima. Karena harus seimbang antara kepentingan pencipta dalam hal ini Pemerintah Kota (Pemkot) Surakarta dengan kepentingan masyarakat yaitu kesamaan bahwa mereka sama-sama ingin membangun Kota Surakarta kedepan menjadi lebih baik. Pada masa pemerintahan Walikota Joko Widodo masalah penataan dan penertiban pedagang kaki lima (PKL) telah menunjukan perubahan yang signifikan dan lebih baik daripada pemerintahan Walikota sebelumnya. Akan tetapi, masalah penataan dan penertiban pedagang kaki lima (PKL) di Kota Surakarta tidak berhenti begitu saja, masih banyak pemasalahan-permasalahan pedagang kaki lima (PKL) yang muncul. Penataan dan penertiban pedagang kaki lima (PKL) bukan hanya kepentingan pemerintah dalam rangka mewujudkan penataan Kota Surakarta yang baik, akan tetapi juga merupakan kepentingan masyarakat Kota Surakarta, khususnya para pedagang kaki lima (PKL).

Masalah Pedagang Kaki Lima (PKL) merupakan masalah yang riskan karena menyangkut kelangsungan hidup terkait dengan mata pencaharian dari para pedagang tersebut. Faktor yang menghambat keberhasilan program penataan pedagang kaki lima (PKL) antara lain ketidakpatuhan dari kelompok sasaran yaitu pedagang kaki lima (PKL) terhadap peraturan. Ketidakpatuhan ini disebabkan oleh para pedagang kaki lima (PKL) memandang tidak tersedianya tempat relokasi atau tempat baru yang strategis berada di pusat keramaian sehingga mudah mendapatkan pembeli. Jadi pelaksanaan dan hasil dari pengelolaan pedagang kaki lima (PKL) di Kota Surakarta belum sesuai harapan. Dalam pelaksanaannya masih mendapat pertentangan dari pedagang kaki lima (PKL) karena tidak mendukung adanya penertiban dan malah semakin banyak pedagang-pedagang baru yang bermunculan. Setelah penertiban pun pedagang kaki lima (PKL) banyak yang kembali ke tempat semula setelah selesainya pengawasan petugas pasca penertiban.

Di satu sisi, untuk mewujudkan kawasan kota yang baik sesuai dengan peraturan yang telah ditetapkan maka Pemerintah Kota Surakarta harus melakukan penertiban dan penataan kawasan pedagang kaki lima (PKL) sesuai dengan peraturan yang ada. Penegakan hukum penertiban dan penataan pedagang kaki lima (PKL) bukan masalah yang mudah, penegakan hukum itu harus didukung dari kedua belah pihak yaitu pemerintah dan pedagang kaki lima (PKL). Di sinilah letak penting dari suatu kesadaran hukum dari masyarakat yaitu pedagang kaki lima (PKL). Masyarakat tidak hanya sekedar diberikan pengetahuan, pemahaman maupun penyuluhan tentang pentingnya penataan dan penertiban pedagang kaki lima (PKL), akan tetapi juga ditumbuhkan kesadaran dari masyarakat itu 
sendiri tentang sisi positifnya atau keuntungan yang diperoleh ketika masyarakat (pedagang) mematuhi penertiban yang dilakukan oleh Pemerintah Kota Surakarta.

Implikasi dan konsekuensi logis yaitu bahwa untuk menciptakan efektivitas sebuah kebijakan diperlukan kerjasama yang baik diantara para penegak hukum dan juga pemerintah. Selain itu juga harus melibatkan peran serta dari masyarakat, baik masyarakat umum dan khususnya para Pedagang Kaki Lima (PKL). Dapat berpengaruh terhadap terhambatnya suatu efektivitas Peraturan Daerah. Produk hukum yang dibuat pemerintah harus memuat segala aspek pendukung yang berkaitan dengan kebijakan yang di buatnya. Jika peraturan yang menjadi pedoman dalam pelaksanaan belum bisa sesuai maka tujuan yang akan di capai juga belum bisa berhasil secara optimal.

\section{PENUTUP}

Keberhasilan penataan Pedagang Kaki Lima (PKL) di Surakarta, berdasar penelitian yang peneliti lakukan, selain faktor-faktor di atas yaitu faktor umumnya sendiri, faktor penegak hukum, faktor sarana atau fasilitas yang mendukung penegakan hukum, faktor masyarakat dan faktor kebudayaan, juga dipengaruhi oleh faktor peran Walikota dalam mengkomunikasikan kebijakan (political will) yang akan diambilnya. Apabila hambatan-hambatan dalam pengelolaan PKL tidak segera ditangani dan diperbaiki, maka tujuan dari efektivitas Peraturan Daerah Kota Surakarta Nomor 3 Tahun 2008 tentang Pengelolaan Pedagang Kaki Lima (PKL) sulit terwujud.

Dari pernyataan-pernyataan tersebut di atas, peneliti dapat memberi saran-saran sebagai berikut :

Pertama, perlu sering diadakannya sosialisasi dan pembinaan kepada PKL di Kota Surakarta tentang peraturan yang terkait dengan program penataan PKL dan komunikasi yang baik antara petugas dan kelompok sasaran sehingga sedikit demi sedikit akan tumbuh kesadaran mereka terhadap peraturan.

Kedua, adanya penambahan modal usaha bagi PKL sehingga mereka dapat memfasilitasi sarana dagang mereka. Karena modal usaha akan sangat membantu pedagang untuk mendapatkan tempat yang layak.

Ketiga, pengadaan tempat relokasi yang strategis berada di tempat keramaian bagi PKL sehingga mereka tidak sulit untuk mendapatkan pembeli dan kembali lagi ke tempat semula.

Keempat, mengaktifkan peran paguyuban yang dibentuk sebagai sarana diskusi sehingga konflik lama yang belum terselesaikan maupun konflik baru yang timbul dapat diatasi dengan segera pada tahap konflik yang masih dini.

Kelima, perlu adanya perbaikan atau revisi dari berbagai peraturan perundangundangan yang menjadi acuan agar tidak terjadi saling bertentangan dan saling menyimpangi. Sehingga diperlukan kajian tersendiri mengenai penyusunan peraturan yang berhubungan langsung dengan pengelolaan PKL. 
Keenam, masyarakat diharapkan lebih aktif dalam memberikan masukan dan juga kontrol terhadap pengelolaan PKL di Kota Surakarta, jangan bersifat acuh dan diam dan beranggapan hanya formalitas pelaksanaannya. Karena budaya hukum masyarakat yang taat dan partisipatif akan sangat menentukan suatu kebijakan.

\section{DAFTAR PUSTAKA}

Budi Winarno. 2007. Kebijakan Publik, Teori dan Proses. Jakarta: Media Presindo.

Bernard L. Tanya, Yoan N. Simanjuntak dan Markus Y. Hage. 2013. Teori Hukum, Strategi Tertib Manusia Lintas Ruang dan Generasi. Yogyakarta: Genta Publishing. Hans Kelsen. 2011. Teori Umum Tentang Hukum dan Negara. Bandung: Nusa Media. Soerjono Soekanto. 1983. Faktor-Faktor yang Mempengaruhi Penegakan Hukum. Jakarta: Rajawali Pers.

2011. Pokok-Pokok Sosiologi Hukum. Jakarta: PT. Raja Grafindo Persada.

Zudan Arif Fakrulloh. 2011. Ilmu Lembaga dan Pranata Hukum. Jakarta: Rajawali Pers. 